Sains Malaysiana 50(6)(2021): 1589-1598

http://doi.org/10.17576/jsm-2021-5006-07

\title{
Antifungal Activity of Aqueous Plant Extracts and Effects on Morphological and Germination of Fusarium Fruit Rot Pathogens
}

(Aktiviti Antikulat Ekstrak Air Tumbuhan dan Kesannya kepada Morfologi dan Percambahan oleh Patogen Reput Buah Fusarium)

\author{
Nur Baiti Abd Murad, Muskhazli Mustafa, Khozirah ShaAri \& Nur Ain IzZati Mohd ZainudiN*
}

\section{ABSTRACT}

Fusarium fruit rot caused by Fusarium species pathogens can be considered a threat to economic loss. The use of synthetic antifungals to control the pathogens has failed to the development of resistance of pathogens. Previous studies reported that plant extracts may contain various bioactive constituents that are able to control pathogen growth. Hence, the aims of this study are to examine the inhibition activity of some plant fresh extracts on mycelial growth and morphological changes of Fusarium oxysporum, F. proliferatum, and F. solani, causal agents of Fusarium fruit rot. Aqueous extract of selected plants was evaluated for their inhibition activity against all the three Fusarium pathogens under in vitro condition using poisoned food bioassay. Averrhoa bilimbi fruit extract demonstrated a highly significant effect against mycelial growth of the pathogens with fungal inhibition percentage of $80.51 \%$ for $\mathrm{F}$. oxysporum, $61.28 \%$ for F. proliferatum and 58.97\% for F. solani. The results showed that the highest formation of 100\% extract has lowered the conidia concentration and germination percentage of $\mathrm{F}$. oxysporum (35.43\%), F. proliferatum (47.61\%), and $\mathrm{F}$. solani $(38.67 \%)$ compared to the control. Significant shriveled mycelia were observed via scanning electron microscope (SEM) on the pathogens treated with A. bilimbi extract, indicating morphological changes occurred in the cell membrane compared to the control in which the mycelia were in normal form. This innovation, which can be prepared and applied at home, has the potential as an eco-friendly and a benign approach to control fruit rot pathogen.

Keywords: Antifungal activity; Fusarium species; in vitro; plant extracts; SEM

ABSTRAK

Penyakit Fusarium reput buah oleh jangkitan patogen spesies Fusarium mengakibatkan kerugian dalam sektor ekonomi. Kekerapan penggunaan racun sintetik antikulat bagi mengawal patogen menyebabkan patogen menjadi lebih rintang. Kajian terdahulu mendapati bahawa ekstrak tumbuhan mempunyai pelbagai kandungan bahan bioaktif yang mampu mengawal pertumbuhan patogen pada hasil tanaman. Oleh itu, matlamat kajian ini adalah untuk mengkaji aktiviti perencatan oleh beberapa ekstrak segar tumbuhan terhadap pertumbuhan miselium dan perubahan morfologi patogen yang menyebabkan penyakit Fusarium reput buah seperti Fusarium oxysporum, F. proliferatum dan F. solani. Ekstrak air daripada beberapa tumbuhan terpilih dinilai dari segi kesan aktiviti perencatannya ke atas ketiga-tiga patogen spesies Fusarium secara in vitro dengan menggunakan kaedah bioassai makanan beracun. Ekstrak buah Averrhoa bilimbi (bilimbing buluh) menunjukkan kesan yang amat ketara dalam mengawal pertumbuhan miselium patogen dengan peratusan perencatan sebanyak $80.51 \%$ bagi F. oxysporum, $61.28 \%$ bagi F. proliferatum dan $58.97 \%$ bagi F. solani. Hasil kajian mendapati kepekatan ekstrak tertinggi sebanyak $100 \%$ memberi kesan dalam penghasilan dan percambahan spora patogen yang rendah, iaitu hanya $35.43 \%$ bagi $\mathrm{F}$. oxysporum, $47.61 \%$ bagi $\mathrm{F}$. proliferatum dan $38.67 \%$ bagi $\mathrm{F}$. solani apabila dibandingkan dengan patogen kawalan masing-masing. Pengecutan miselium yang ketara ke atas patogen yang diberikan rawatan ekstrak buah belimbing buluh dapat diperhatikan melalui SEM yang menunjukkan bahawa terdapat perubahan morfologi pada sel membran jika dibandingkan dengan patogen kawalan yang masih dalam keadaan normal. Inovasi yang dapat dihasilkan dan diguna pakai di rumah ini mempunyai potensi sebagai salah satu cara pengawalan patogen penyakit reput buah yang mesra alam dan menjimatkan kos.

Kata kunci: Aktiviti antikulat; ekstrak tumbuhan; in vitro; SEM; spesies Fusarium 


\section{INTRODUCTION}

The genus Fusarium has been reported as among the most significant genera that cause fungal rot on fruits and vegetables through infection and colonization during preharvest and post-harvest storage. The disease might affect the nutritional value of the crops and mycotoxin production by the fungal species under favorable condition, which may also lead to a significant economic loss (Zakaria 2017; Zakaria et al. 2012). Additionally, Fusarium species are ubiquitous and able to grow on various substrates and survive in various environmental conditions. Their survival depends on abiotic factors including temperature and water activity (Zakaria 2017). Fusarium pathogens can cause a wide range of plant diseases including wilt, root rot, stem rot, fruit rot, blight, and cankers in plants such as industrial crops, fruit crops, leguminous and ornamentals plants (Ma et al. 2013). Fusarium oxysporum, $F$. proliferatum, and $F$. solani are the most frequently reported Fusarium species that cause fruit rot (Abd Murad et al. 2017). In this matrix, the fungi are responsible for the off-flavor formation by causing heating in the fruit and utilizing the sugars inside the fruit as their energy source. In addition, the pathogens degrade the lipids and proteins due to their potential to synthesis various hydrolytic enzymes, which gradually leads to production of volatile metabolites and compounds. Those factors lead to allergy, hence causing the fruits to lose their quality and nutritional values (da Cruz Cabral et al. 2013). Production of mycotoxins may occur at the field and in storage, which may rise during handling. Therefore, to lessen the risk on human and animal health, it is essential to kill the fungal colony in crops, fresh fruits and vegetables to prevent mycotoxin accumulation.

Since years ago, fungal spoilage has been controlled by the application of synthetic preservatives and fungicides. Unfortunately, the unselective and excessive use of these chemicals has affected human and animal health due to their carcinogenicity, teratogenicity, high and acute residual toxicity, hormonal imbalance as well as spermatotoxicity properties (da Cruz Cabral et al. 2013). This can also lead to environmental pollution due to high toxic residual and long degradation period in food, soil and water sources as well as the development of pathogen resistance. Considering all these factors, safer alternatives and environmentally friendly antifungal agents need to be developed. Alternative agents include plant extracts that possess a huge potential to substitute the synthetic fungicides at a cheaper cost with less toxicity, local availability, biodegradability and exhibiting more freshlike and natural characteristics including antioxidants that are beneficial for the human health (Breda et al. 2016; da Cruz Cabral et al. 2013).
Plant extract contains a mixture of chemicals, where more than one antifungal compound that can work synergistically to inhibit the growth of fungal pathogens (Shuping \& Eloff 2017). This can limit the ability of fungal pathogens to build resistance attributable to different compounds, which might have different mechanisms against the metabolic process in the pathogens. In addition, Mdee et al. (2009) hypothesized that invasive plant species are resilient to fungal pathogens since these pathogens are the limiting factor in determining the extent of the plants into other environments. There are plenty of plant species that have been explored for their antifungal activity and ability to produce a diversity of antimicrobial properties such as phytoalexins and phytoanticipins that differ in molecular weight, structure, functionality, and compound class such as alkaloids, flavonoids, terpenoids, phenolics, glycosides, tannins, and fatty acids (Raut \& Karuppayil 2014). Therefore, this study was conducted to examine the inhibition activity of some plant fresh extracts on mycelial growth and morphological changes of Fusarium fruit rot pathogens.

\section{MATERIALS AND METHODS}

\section{PREPARATION OF PLANT EXTRACT}

The fresh plant parts (Pilea microphylla, Peperomia pellucida, Persicaria odorata, Cymbopogon citratus, Tamarindus indica, Garcinia mangostana, and Averrhoa bilimbi) were collected and cleaned using running tap water (Table 1), and then were surface-sterilized using sterile distilled water for $15 \mathrm{~min}$ and tossed at $25 \pm 2{ }^{\circ} \mathrm{C}$. Each selected plant part (500 g) was blended in $1000 \mathrm{~mL}$ sterile distilled water. They were homogenized using a blender (Waring Commercial Products, Torrington, CT, USA) under high mode for $2 \mathrm{~min}$. The water extract was then filtered through four folds of sterile cheesecloth followed by Whatman No. 1 filter paper (Merck KGaA, Darmstadt, Germany) (Nur Fatimma et al. 2018). The extracts were kept at $4{ }^{\circ} \mathrm{C}$ until further use.

\section{SOURCE OF FUNGAL CULTURE}

Fungal pathogens used in this study were $F$. oxysporum $\mathrm{B} 713 \mathrm{~T}$ originally isolated from tomato, F. solani M1799C isolated from cucumber and $F$. proliferatum B2433B isolated from banana. All the fungal species in this study were identified based on morphological and molecular characterization (Table 2) together with their origin. The fungal cultures were obtained from Mycology Laboratory of Department of Biology, Faculty of Science, Universiti Putra Malaysia. The fungi were sub-cultured onto potato dextrose agar (PDA) and incubated at $28 \pm 2$ ${ }^{\circ} \mathrm{C}$ for 7 days until further use. 
TABLE 1. Selected plant materials freshly used for aqueous extraction

\begin{tabular}{lllll}
\hline Scientific name & Family & Common name & Plant part & Location in Malaysia \\
\hline Pilea microphylla & Urticaceae & Rockweed & Leaf & Semenyih, Selangor \\
Peperomia pellucida & Piperaceae & Pepper elder & Leaf & Meru, Selangor \\
Persicaria odorata & Polygonaceae & $\begin{array}{l}\text { Vietnamese } \\
\text { coriander }\end{array}$ & Leaf & Tanjong Karang, Selangor \\
Cymbopogon citratus & Poaceae & Lemongrass & Leaf and stem & Tanjong Karang, Selangor \\
Tamarindus indica & Fabaceae & Tamarind & Leaf, pod and pulp & UPM, Serdang, Selangor \\
Garcinia mangostana & Clusiaceae & Mangosteen & Leaf and peel & Maran, Pahang \\
Averrhoa bilimbi & Oxalidaceae & Bilimbi & Leaf and fruit & UPM, Serdang, Selangor \\
\hline
\end{tabular}

TABLE 2. List of Fusarium species associated with fruit rot disease

\begin{tabular}{|c|c|c|c|c|c|c|}
\hline $\begin{array}{l}\text { Isolate } \\
\text { no. }\end{array}$ & Species name & Origin & Host source & Disease & $\begin{array}{l}\text { Disease } \\
\text { severity index } \\
(\%)\end{array}$ & Reference \\
\hline B713T & F. oxysporum & $\begin{array}{l}\text { Kajang, } \\
\text { Selangor }\end{array}$ & Tomato & Fruit rot & 87.5 & $\begin{array}{l}\text { Abu Bakar et al. } \\
\text { (2013) }\end{array}$ \\
\hline B2433B & F. proliferatum & $\begin{array}{l}\text { Serdang, } \\
\text { Selangor }\end{array}$ & Banana & Fruit rot & 100 & $\begin{array}{l}\text { Abd Murad et al. } \\
\text { (2017) }\end{array}$ \\
\hline M1799C & F. solani & $\begin{array}{l}\text { Bukit } \\
\text { Rambai, } \\
\text { Melaka }\end{array}$ & Cucumber & $\begin{array}{l}\text { Fusarium wilt and } \\
\text { fruit rot }\end{array}$ & 100 & Asma (2019) \\
\hline
\end{tabular}

\section{SCREENING OF INHIBITION ACTIVITY OF PLANT EXTRACTS}

The plant extracts were sterilized by filtering through syringe filter with $0.22 \mu \mathrm{m}$ pore size. The inhibitory screening test was conducted by poisoned food method. Approximately, $10 \mathrm{~mL}$ of plant extracts were added to 10 $\mathrm{mL}$ of PDA in Petri plate $(90 \mathrm{~mm})$ aseptically and allowed to solidify. A mycelia disc of $5 \mathrm{~mm}$ in diameter of the pure culture from 7-day old culture of each tested pathogen was inoculated on the centre of the medium using a cork borer $(5 \mathrm{~mm})$ and incubated at room temperature $25 \pm 2$ ${ }^{\circ} \mathrm{C}$. The plates with sterile distilled water alone served as control. Five technical replicates were used and the whole experiment was repeated twice in a completely randomized design (CRD). The mycelial growth was determined at day-7 after inoculation (DAI) (Nur Fatimma et al. 2018). 
The diameter of inhibition zone was measured for successive 7 days. Percentage inhibition was calculated from data obtained using the formula by Mondali et al. (2009): \% FG $=[(\mathrm{DC}-\mathrm{DR}) / \mathrm{DC}] \times 100$; where $\% \mathrm{FG}=$ percentage of inhibition of fungi growth; $\mathrm{DC}=$ diameter of control; DR = diameter of test.

\section{DETERMINATION OF CONIDIA CONCENTRATION AND GERMINATION PERCENTAGE}

Petri plates from each replicate for each treatment and control after 7 days of incubation period were flooded with $10 \mathrm{~mL}$ distilled water, while the colony surface was scrapped with a sterile glass rod and the resulting suspension was filtered through sterile cheesecloth. The conidia were counted using a hemocytometer under a light microscope (OLYMPUS CX31) at magnification 40 $\times 10$. The conidia were also incubated in distilled water for $24 \mathrm{~h}$ to record the germination rate. Germination was recorded once the germ tube could be visibly observed (Nur Fatimma et al. 2018). The percentage of conidia germination was calculated using the following formula adopted from Dey et al. (2013): PS (\%) =S/B $\times 100$; where PS $(\%)=$ percent of spore germination; $S=$ number of spores germinated; $\mathrm{B}=$ number of spores observed.

\section{SCANNING ELECTRON MICROSCOPY (SEM)}

Sample preparation was conducted following the standard procedures by Gumgumjee et al. (2012) and Serpa et al. (2012). Briefly, fungal samples from both control and treated plates were cut into small plugs of 5-8 $\mathrm{mm}^{3}$ and soaked in $2.5 \%$ glutaraldehyde in $0.2 \mathrm{M}$ cacodylate buffer at $\mathrm{pH} 7.2$ for $4-6 \mathrm{~h}$ at $4{ }^{\circ} \mathrm{C}$. The samples were washed with $0.1 \mathrm{M}$ sodium cacodylate buffer for 3-time changes of 10 min each and were post-fixed in aqueous $1 \%$ osmium tetroxide $\left(\mathrm{OsO}_{4}\right)$ for $2 \mathrm{~h} \mathrm{sat} 4{ }^{\circ} \mathrm{C}$. The samples were washed again with the same buffer for 3-time changes of $10 \mathrm{~min}$ each and were dehydrated in a range series (from 35 to $100 \%$ ) of acetone. The samples were transferred into sample basket and put into critical point dryer (CPD) for $90 \mathrm{~min}$. The samples were mounted onto the stub using double sided tape and placed into a sputter coater for gold coating. The mounted samples were photographed using a scanning electron microscope (JSM 6400, JEOL Ltd., Japan).

\section{DATA COLLECTION AND STATISTICAL ANALYSIS}

The experimental data were analyzed using IBM SPSS Statistics 22 for Windows System. In vitro study of mycelial growth was measured in diameter $(\mathrm{mm})$ with the data type converted to percentage of inhibition. The data of inhibition percentage were analyzed using one-way analysis of variance (ANOVA). Tukey's HSD test was used to find the significant difference among means at the probability level $p<0.05$. Two-way ANOVA was applied to determine the significant difference in total number of conidia (conidia/mL) and germination rate $(\%)$ between the control and different treatment concentrations for each different fungal pathogen (Nur Fatimma et al. 2018).

\section{RESULTS AND DISCUSSION}

Development of alternative antifungal substances such as plant extracts to substitute the synthetic chemical fungicides in controlling fungal diseases of plants is a great effort to reduce health risk effect. The plant extracts contain chemical mixtures that can work synergistically to inhibit the growth of plant fungal pathogens. A plant extract may contain more than one antifungal component that can act in different mechanisms of activity to reduce the resistance development of the pathogens (Gholamnezhad 2019; Shuping \& Eloff 2017). In this study, the plant extracts were freshly prepared using sterile distilled water as the solvent to exhibit homemade plant extract without interfering of other chemical solvents. The extracts are able to control pathogens, which had been traditionally practiced by the folks many years ago (Nur Fatimma et al. 2018; Shuping \& Eloff 2017).

Based on the inhibitory screening test, the result showed that different aqueous fresh plant extracts offer different inhibition effects against the mycelial growth of the three Fusarium species. The A. bilimbi fruit extract showed a highly significant inhibition effect on mycelial growth of all the Fusarium species than the other extracts compared to their respective control (Figure $1)$. The percentage inhibition of mycelial growth for $F$. oxysporum, $F$. proliferatum, and $F$. solani was recorded at $80.51,61.28$, and $58.97 \%$, respectively. Other plant extracts showed varies inhibition effects on the mycelial growth (Table 3). Averrhoa bilimbi fruit extract demonstrated a highly significant effect in inhibiting the mycelial growth of all the Fusarium species (Figure 1 ), thus, it was selected for further investigation on the effects of concentration on sporulation and conidial germination as well as micrograph scanning electron microscopy analysis.

In this study, the aqueous extracts of the selected plant species demonstrated varied antifungal potential when tested against Fusarium rot pathogens. The results 
showed the degree of mycelial growth inhibition during in vitro screening, which depended on the chemical composition of plant species and its extracted part. Based on the in vitro test, it was clearly showed that $A$. bilimbi fruit extract possessed the highest inhibition percentage against mycelial growth of all the three Fusarium rot pathogens species compared to the other plant extracts and their respective controls. Furthermore, the number of conidia production and percentage of conidial germination of all the pathogens tested were significantly reduced according to the concentrations of the extract applied compared to the controls due to the presence of antifungal properties in the extract. Averrhoa bilimbi fruit extract was reported to have one of the crucial pharmacological profiles, which is antimicrobial due to the presence of some of bioactive compounds such as alkaloid, tannins, saponins, flavonoids, cardiac glycosides, triterpenes, phenolic, triterpenoid, oxalic acids, D-3-hexanal, citric acid, and cyaniding-3-O- $\beta$-D-glucoside. Those bioactive compounds contribute to its antifungal, antimicrobial, antilipidemic and antioxidant properties (Carandang et al. 2017; Nakyinsige et al. 2016; Zulhaimi et al. 2017).

Moreover, this finding is in agreement with a previous study reviewed by Alhassan and Ahmed (2016) and Aziz (2016), which reported a positive antimicrobial activity of aqueous extracts of fruits and leaves of $A$. bilimbi against several Gram-positive bacteria such as Staphylococcus aureus, Staphylococcus epidermis, Bacillus cereus, Corneybacterium diphtheria, and Kochuria rhizophilia as well as against several Gram-negative bacteria such as Salmonella typhi, Citrobacter fuendii, and Aeromonas hydrophila. Furthermore, Aziz et al. (2014) found that the aqueous extract of $A$. bilimbi fruit produced a maximum efficacy against most of the bacteria compared to ethanol and methanol extracts. However, there is lack of report on the efficacy of $A$. bilimbi fruit extract against the growth of fungal species, and yet a finding from a study by Rana et al. (2014) showed a positive effect of $A$. bilimbi fruit methanol extract on the growth of Candida albicans and Aspergillus niger.

It has been suggested that the antimicrobial activity of $A$. bilimbi fruit is attributed by its highly acidic $\mathrm{pH}$ (de Lima et al. 2001) as the $\mathrm{pH}$ of $A$. bilimbi extracts ranges at $\mathrm{pH}$ 0.9-1.5. Averrhoa bilimbi fruit has a high level of oxalic acid ranging at $8.57-10.32 \mathrm{mg} / 100 \mathrm{~g}$ and ascorbic acid at 32.23-60.95 mg/100 g. These organic acids are known to possess antimicrobial activity and can penetrate the cell membrane effectively in their undissociated form (Nakyinsige et al. 2016).

Several theories of inhibition mechanism upon fungal growth involving the organic acids have been discussed. Organic acids will decrease the $\mathrm{pH}$ value of the media and this condition will cause acidification in the pathogen cell where a large amount of energy is required to sustain the homeostasis of the cell intracellular $\mathrm{pH}$, thus, affecting its growth. This manifestation is progressed and continued by membrane disruption of the pathogen cell, followed by interruption of metabolic reactions in the pathogen cell and finally leading to the accumulation of toxic anions inside the pathogen cell (Elsherbiny et al. 2016).

However, Hassan et al. (2015) suggested that the hydrophobic feature of most organic acids is the main factor in the inhibitory mechanism. It allows free organic acid diffusion in the protonized form to pass through pathogen cell membrane. This will then result in a higher intracellular $\mathrm{pH}$ than the extracellular $\mathrm{pH}$. Thus, the $\mathrm{pH}$ difference will cause acid dissociation as it arrives at the cytoplasm of the cell and reduces the intracellular $\mathrm{pH}$ by releasing the proton. In order to prevent further reduction in cytoplasmic $\mathrm{pH}$, the pathogen assigns the main part of its energy content to eradicate the newly formed protons, resulting in slower growth kinetics. Conclusively, the low $\mathrm{pH}$ of the media will successively reduce the growth rate and lengthen the lag phase of the pathogens, thus leading to the appearance of inhibition zone on the inoculated media after incubation period.

The concentration of $A$. bilimbi fruit extract has significantly affected both numbers of conidia produced and percentage of germinated conidia of all the Fusarium species pathogens after $24 \mathrm{~h}$ incubation (Table 4 ). The numbers of observed conidia and percentage of germinated conidia were significantly different between the respective control plates and treated plates for all the Fusarium species at all the extract concentration levels except for $F$. proliferatum, where its conidial germination for the control was not significantly different from those treated with concentration at $10 \%$. The highest recorded percentage of conidial germination of $F$. oxysporum was at $10 \%$ concentration with $70.54 \%$, while the lowest was at $100 \%$ concentration with $35.60 \%$. The highest percentage of conidial germination of $F$. proliferatum was also at $10 \%$ concentration with $74.51 \%$, while the lowest percentage was at $75 \%$ concentration with $44.89 \%$, though it showed no significant difference from those germinated conidia at $100 \%$ concentration with $47.61 \%$. This finding pattern was subsequently occurred for $F$. solani as well, but at a lower extract concentration. The highest recorded percentage of conidial germination of $F$. solani was also at $10 \%$ concentration with $73.88 \%$, but no significant difference was shown for conidial germination at $25 \%$ concentration with $68.29 \%$. The lowest percentage of the conidial germination was at $100 \%$ concentration with $38.97 \%$. 
In this study, the pathogen growth and conidia germination rates were significantly decreased upon exposure to the $A$. bilimbi fruit aqueous extract according to their concentrations due to the presence of the phytochemical components that mainly consist of several organic acids that may have antifungal activity. This finding is in correlation with that obtained by Hassan et al. (2015) where the growth of Fusarium species in their study was completely inhibited by the presence of propionic acid and sorbic acid in the media.

Based on the SEM micrographs, all the non-treated fungal mycelia were observed normal in long tubular shape with smooth surface (Figure 2, A1-C1 and A3-C3) and fine condition, while those fungal mycelia treated with aqueous $A$. bilimbi fruit extract appeared differently to the control due to the significant effect of the extract on the mycelial morphology (Figure 2, A2-C2 and A4-C4). The mycelia were shrunken, crenate and distorted, and perhaps there were some alterations that occurred in cell membrane permeability of the mycelia of the fungal pathogens.

The SEM images of Fusarium species (Figure 2) proved that $A$. bilimbi extract could acceptably control the growth of the pathogens by altering the morphology of the mycelia, making them defected and finally affecting the pathogens growth kinetics. Additionally, the finding from the SEM micrograph is parallel with that of da Cruz Cabral et al. (2013), who stated that the low pH will result in optimal inhibitory activity of the extract since the acid condition contributed by the extract will allow the bounded form of molecules freely across the plasma membrane of the target pathogen cell. This makes the cytoplasmatic $\mathrm{pH}$ of the pathogen cell to decline due to the entry of the bounded form of the extract compound causing rupture of certain metabolic reactions of the pathogens, leading to the permeabilization of the cytoplasmic membrane, and this may cause cell death.

The water extracts have been providing the scientific basis for the use of these plants traditionally to treat diseases by demonstrating their antimicrobial activity. However, further studies need to be done to determine different types of compound produced by the plant extracts to support the study finding. This is because optimal effectiveness of the medicinal plants could be achieved by more than one main active components via combined actions of different compounds that initially present in the plants.

TABLE 3. Inhibitory effects of plant aqueous extracts using poisoned food method against Fusarium spp. pathogens on day-7 after inoculation

\begin{tabular}{|c|c|c|c|}
\hline \multirow{2}{*}{ Treatments } & \multicolumn{3}{|c|}{ Percentage of Inhibition of mycelial growth of Fusarium spp. pathogens } \\
\hline & F. oxysporum & F. proliferatum & F. solani \\
\hline P. microphylla (leaf) & $26.41 \pm 1.46^{\mathrm{f}}$ & $0^{\mathrm{a}}$ & $0^{\mathrm{a}}$ \\
\hline P. pellucida (leaf) & $0^{\mathrm{a}}$ & $0^{\mathrm{a}}$ & $0^{\mathrm{a}}$ \\
\hline P. odorata (leaf) & $0^{\mathrm{a}}$ & $20.51 \pm 1.28^{c}$ & $0^{\mathrm{a}}$ \\
\hline C. citratus (leaf) & $17.18 \pm 1.46^{\mathrm{e}}$ & $32.31 \pm 1.07^{\mathrm{e}}$ & $8.97 \pm 1.29^{\mathrm{c}}$ \\
\hline C. citratus (stem) & $3.33 \pm 1.46^{\mathrm{b}}$ & $18.21 \pm 1.07^{\mathrm{c}}$ & $4.62 \pm 1.46^{\mathrm{b}}$ \\
\hline Tamarindus indica (leaf) & $12.56 \pm 1.07^{\mathrm{d}}$ & $31.28 \pm 1.46^{\mathrm{e}}$ & $9.23 \pm 1.08^{\mathrm{c}}$ \\
\hline Tamarindus indica (pod) & $13.08 \pm 1.07^{\mathrm{d}}$ & $28.47 \pm 1.07^{\mathrm{d}}$ & $0^{\mathrm{a}}$ \\
\hline Tamarindus indica (pulp) & $30.77 \pm 1.28^{\mathrm{g}}$ & $0^{\mathrm{a}}$ & $23.56 \pm 1.46^{\mathrm{d}}$ \\
\hline Garcinia mangostana (leaf) & $26.67 \pm 1.09^{\mathrm{f}}$ & $0^{\mathrm{a}}$ & $6.15 \pm 1.07^{b}$ \\
\hline Garcinia mangostana (peel) & $29.75 \pm 1.07^{\mathrm{g}}$ & $0^{\mathrm{a}}$ & $0^{\mathrm{a}}$ \\
\hline Averrhoa bilimbi (leaf) & $6.15 \pm 1.66^{\mathrm{c}}$ & $10.51 \pm 1.07^{\mathrm{b}}$ & $4.36 \pm 1.46^{\mathrm{b}}$ \\
\hline Averrhoa bilimbi (fruit) & $80.51 \pm 1.07^{\mathrm{h}}$ & $61.28 \pm 1.67^{\mathrm{f}}$ & $58.97 \pm 1.29^{\mathrm{e}}$ \\
\hline Control & $0^{\mathrm{a}}$ & $0^{\mathrm{a}}$ & $0^{\mathrm{a}}$ \\
\hline
\end{tabular}

The values are the percentage of means of five replications of the inhibition zone measurements followed by the same letter for the extracts that do not show a significant effect to each other compared to the control of respective Fusarium species 
TABLE 4. Number of conidia and percentage of conidia germination after $24 \mathrm{~h}$ incubation of $F$. oxysporum, F. proliferatum, and $F$. solani treated with Averrhoa bilimbi fruit extract

\begin{tabular}{|c|c|c|c|c|c|c|}
\hline \multirow[b]{2}{*}{$\begin{array}{l}\text { Concentration } \\
(\% \mathrm{v} / \mathrm{v})\end{array}$} & \multicolumn{2}{|c|}{ F. oxysporum } & \multicolumn{2}{|c|}{ F. proliferatum } & \multicolumn{2}{|c|}{ F. solani } \\
\hline & $\begin{array}{c}\text { No. of conidia } \\
\left(\text { conidial } \times 10^{4} / \mathrm{mL}\right)\end{array}$ & $\begin{array}{c}\text { Conidia } \\
\text { germination }(\%)\end{array}$ & $\begin{array}{c}\text { No. of conidia } \\
\left(\text { conidial } \times 10^{4} / \mathrm{mL}\right)\end{array}$ & $\begin{array}{c}\text { Conidia } \\
\text { germination (\%) }\end{array}$ & $\begin{array}{l}\text { No. of conidia } \\
\left(\text { conidial } \times 10^{4} / \mathrm{mL}\right)\end{array}$ & $\begin{array}{c}\text { Conidia } \\
\text { germination }(\%)\end{array}$ \\
\hline 100 & $5.93 \pm 0.40^{\mathrm{a}}$ & $35.43 \pm 1.41^{\mathrm{a}}$ & $5.27 \pm 0.68^{\mathrm{a}}$ & $47.61 \pm 2.51^{\mathrm{a}}$ & $1.17 \pm 0.14^{\mathrm{a}}$ & $38.67 \pm 1.15^{\mathrm{a}}$ \\
\hline 75 & $9.77 \pm 1.08^{b}$ & $48.55 \pm 1.50^{\mathrm{b}}$ & $4.77 \pm 0.25^{\mathrm{a}}$ & $44.74 \pm 2.35^{\mathrm{ab}}$ & $3.17 \pm 0.14^{\mathrm{b}}$ & $59.04 \pm 1.58^{\mathrm{b}}$ \\
\hline 50 & $11.70 \pm 0.79^{b}$ & $52.30 \pm 1.12^{\mathrm{c}}$ & $6.43 \pm 0.51^{\mathrm{a}}$ & $52.67 \pm 1.63^{\mathrm{bc}}$ & $3.33 \pm 0.14^{b}$ & $65.39 \pm 2.51^{b c}$ \\
\hline 25 & $17.53 \pm 1.17^{\mathrm{c}}$ & $64.46 \pm 1.62^{\mathrm{d}}$ & $6.70 \pm 0.66^{\mathrm{ab}}$ & $55.97 \pm 2.11^{\mathrm{c}}$ & $5.67 \pm 0.72^{\mathrm{c}}$ & $68.40 \pm 1.26^{\mathrm{cd}}$ \\
\hline 10 & $19.92 \pm 1.23^{c}$ & $70.54 \pm 0.19^{\mathrm{e}}$ & $9.25 \pm 1.09^{b}$ & $70.63 \pm 0.58^{d}$ & $5.58 \pm 0.38^{c}$ & $73.88 \pm 2.48^{\mathrm{d}}$ \\
\hline 0 & $39.77 \pm 1.97^{\mathrm{d}}$ & $88.32 \pm 0.02^{\mathrm{f}}$ & $23.17 \pm 1.53^{\mathrm{c}}$ & $74.51 \pm 2.11^{\mathrm{d}}$ & $24.58 \pm 0.52^{\mathrm{d}}$ & $84.95 \pm 3.63^{e}$ \\
\hline
\end{tabular}

The values are the means and percentage of means of five replications of the respective number of conidia and conidia germination followed by the same letter for the concentration of the extracts that not show a significant effect between different concentrations of the extract compared to the control of respective Fusarium species

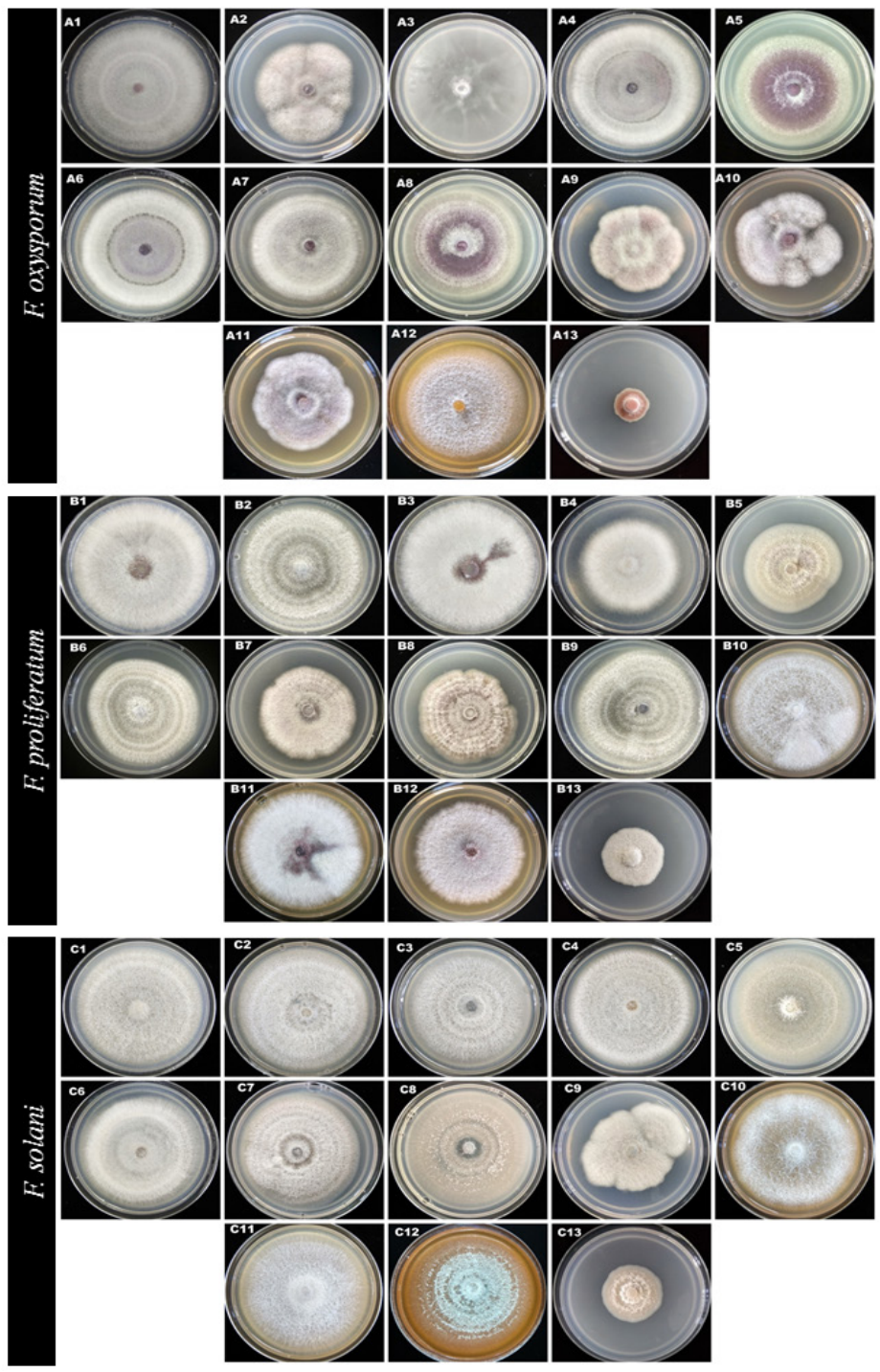

FIGURE 1. Effects of selected plant extracts on mycelial growth of Fusarium pathogens. Control (A/B/C-1), culture treated with: P. microphylla leaf extract (A/B/C-2), P. pellucida leaf extract (A/B/C-3), P. odorata leaves extract (A/B/C-4), C. citratus leaves extract (A/B/C-5), C. citratus stem extract (A/B/C-6), T. indica leaf extract (A/B/C-7), T. indica pod extract (A/B/C-8), T. indica pulp extract (A/B/C-9), G. mangostana leaf extract (A/B/C-10), G. mangostana peel extract

(A/B/C-11), A. bilimbi leaf extract (A/B/C-12) and A. bilimbi fruit extract (A/B/C-13) 

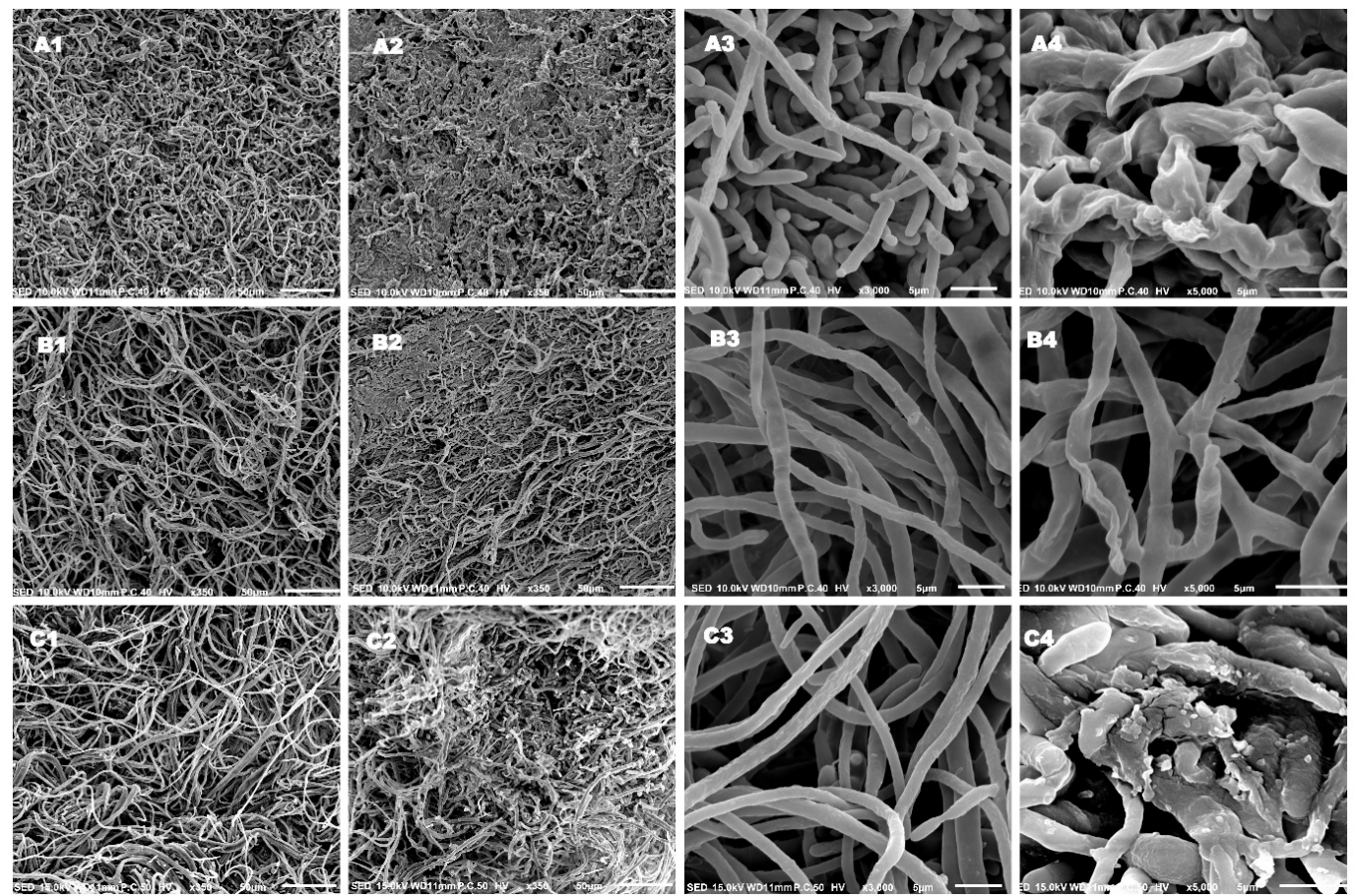

FIGURE 2. Scanning electron microscope micrographs of non-treated and A. bilimbi fruit extract treated mycelia of Fusarium spp. pathogens. Mycelia of F. oxysporum from non-treated plate (control) (A1), deformed mycelia from treated plate (A2), well-formed hyphae from non-treated plate (A3) and shrunken and crenate hyphae from treated plate (A4). Mycelia of F. proliferatum from non-treated plate (control) (B1), malformed mycelia from treated plate (B2), normal hyphae from non-treated plate (B3) and shriveled hyphae from treated plate (B4). Mycelia of F. solani from non-treated plate (control) (C1), mutilated mycelia from treated plate (C2), well-defined hyphae from non-treated plate (C3) and distorted and collapsed hyphae from treated plate (C4)

\section{CONCLUSION}

Based on the findings of this study, A. bilimbi fruit extract has the potential to be used as a natural antifungal to control the plant diseases caused by Fusarium species using the naturally occurring substances in the extract that are safe to both human and environment at affordable preparation cost compared to chemically formulated fungicides. Further analyses on bioactive compounds of the plant are necessary to understand the biochemical mechanism actions of the plant and to afford the bases for developing a new bio-fungicide from the plant either as a pure compound or standardized extract using an advanced and sophisticated technology.

\section{ACKNOWLEDGEMENTS}

This work was funded by the Ministry of Higher Education under Fundamental Research Grant Scheme (FRGS/1/2018/STG03/UPM/02/12). Nur Baiti A.M received a scholarship from the Graduate Research Fellowship (GRF), UPM. The authors are thankful to Mrs. Nor Hidayah Husain for technical assistance.

\section{REFERENCES}

Abd Murad, N.B., Mohamed Nor, N.M.I., Shohaimi, S. \& Mohd Zainudin, N.A.I. 2017. Genetic diversity and pathogenicity of Fusarium species associated with fruit rot disease in banana across Peninsular Malaysia. Journal of Applied Microbiology 123(6): 1533-1546. 
Abu Bakar, A.I., Nur Ain Izzati, M.Z. \& Umi Kalsom, Y. 2013. Diversity of Fusarium species associated with post-harvest fruit rot disease of tomato. Sains Malaysiana 42(7): 911920.

Alhassan, A.M. \& Ahmed, Q.U. 2016. Averrhoa bilimbi Linn.: A review of its ethnomedicinal uses, phytochemistry, and pharmacology. Journal of Pharmacy \& Bioallied Science 8(4): 265-271.

Asma, A. 2019. Characterization of Fusarium species associated with wilt disease of cucurbit and effectiveness of Trichoderma asperellum as biological enhancer. Universiti Putra Malaysia. Ph.D. Thesis (Unpublished).

Aziz, M.A., Rahman, S., Islam, M. \& Begum, A.A. 2014. A comparative study on antibacterial activities and cytotoxic properties of various leaves extracts of Averrhoa bilimbi. International Journal of Pharmaceutical Sciences and Research 5(3): 913-918.

Aziz, N.A. 2016. A review of the antimicrobial properties of three selected underutilized fruits of Malaysia. International Journal of Pharmaceutical and Clinical Research 8(9): 1278-1283.

Breda, C.A., Gasperini, A.M., Garcia, V.L., Monteiro, K.M., Bataglion, G.A., Eberlin, M.N. \& Duarte, M.C.T. 2016. Phytochemical analysis and antifungal activity of extracts from leaves and fruit residues of Brazilian Savanna plants, aiming its use as safe fungicides. Natural Product and Bioprospect 6(4): 195-204.

Carandang, V.C.A., Hernandez, M.R.V. \& Alvaira, C.E. 2017. In vitro screening of anti-fungal effect of Averrhoa bilimbi leaves methanolic extract against Microsporum canis. Lyceum of the Philippines-St. Cabrini College of Allied Medicine Research 2(2): 58-66.

da Cruz Cabral, L., Pinto, V.F. \& Patriarca, A. 2013. Application of plant derived compounds to control fungal spoilage and mycotoxin production in foods. International Journal of Food Microbiology 166(1): 1-14

de Lima, V.L.A.G., Mélo, E.D.A. \& Lima, L.D.S. 2001. Physicochemical characteristics of bilimbi (Averrhoa bilimbi L.). Revista Brasileira de Fruiticultura 23(2): 421423.

Dey, U., Harlapur, S.I., Dhutraj, D.N., Suryawanshi, A.P., Jagtap, J.P., Apet, K.T., Badgujar, S.L., Gholve, V.M., Kamble, H.N., Kuldhar, D.P. \& Wagh, S.S. 2013. Effect of fungicides, botanicals, bioagents and Indigenous Technology Knowledge (ITK's) on germination of urediniospores of Puccinia sorghi in vitro. African Journal of Agricultural Research 8(39): 4960-4971.

Elsherbiny, E.A., Amin, B.H. \& Baka, Z.A. 2016. Efficiency of pomegranate (Punica granatum L.) peels extract as a high potential natural tool towards Fusarium dry rot on potato tubers. Postharvest Biology and Technology 111: 256-263.

Gholamnezhad, J. 2019. Effect of plant extracts on activity of some defense enzymes of apple fruit in interaction with Botrytis cinerea. Journal of Integrative Agriculture 18(1): 115-123.
Gumgumjee, N.M., Khedr, A. \& Hajar, A.S. 2012. Antimicrobial activities and chemical properties of Tamarindus indica $\mathrm{L}$. leaves extract. African Journal of Microbiology Research 6(32): 6172-6181.

Hassan, R., El-Kadi, S. \& Sand, M. 2015. Effect of some organic acids on some fungal growth and their toxins production. International Journal of Advances in Biology 2(1): 1-11.

Ma, L.J., Geiser, D.M., Proctor, R.H., Rooney, A.P., O’Donnell, K., Trail, F., Gardiner, D.M., Manners, J.M. \& Kazan, K. 2013. Fusarium pathogenomics. Annual Review of Microbiology 67: 399-416.

Mdee, L.K., Masoko, P. \& Eloff, J.N. 2009. The activity of extracts of seven common invasive plant species on fungal phytopathogens. South African Journal of Botany 75(2): 375-379.

Mondali, N., Mojumdar, A., Chatterje, S., Banerjee, A., Datta, J.K. \& Gupta, S. 2009. Antifungal activities and chemical characterization of neem leaf extracts on the growth of some selected fungal species in vitro culture medium. Journal Application Science Environment Management 13(1): 49-53.

Nakyinsige, K., Abdul Rahman, N.S., Salwani, M.S., Abd Hamid, A., Adeyemi, K.D., Sakimin, S.Z. \& Sazili, A.Q. 2016. Effect of belimbing buluh (Averrhoa bilimbi) juice extract on oxidative stability and microbiological quality of spent chicken meat. International Food Research Journal 23(6): 2675-2680.

Nur Fatimma, A., Munirah, M.S., Sharifah Siti Maryam, S.A.R., Najihah, A. \& Nur Ain Izzati, M.Z. 2018. Efficacy of Allium sativum extract as post-harvest treatment of fruit rot of mango. Plant Pathology and Quarantine 8(2): 144-152.

Rana, S.M.M., Billah, M.M., Hossain, M.S., Saifuddin, A.K.M., Islam, S.K.M.A., Banik, S., Naim, Z. \& Raju, G.S. 2014. Susceptibility of microorganism to selected medicinal plants in Bangladesh. Asian Pacific Journal of Tropical Biomedicine 4(11): 911-917.

Raut, J.S. \& Karuppayil, S.M. 2014. A status review on the medicinal properties of essential oils. Industrial Crops and Products 62: 250-264.

Serpa, R., França, E.J.G., Furlaneto-Maia, L., Andrade, C.G.T.J., Diniz, A. \& Furlaneto, M.C. 2012. In vitro antifungal activity of the flavonoid baicalein against Candida species. Journal of Medical Microbiology 61(Pt 12): 1704-1708.

Shuping, D.S.S. \& Elof, J.N. 2017. The use of plants to protect plants and food against fungal pathogens: A review. African Journal of Traditional Complement Alternative Medicines 14(4): 120-127.

Zakaria, L. 2017. Mycotoxigenic Fusarium species from agricultural crops in Malaysia. JSM Mycotoxins 67(2): 67-75.

Zakaria, L., Chik, M.W., Heng, K.W. \& Salleh, B. 2012. Fusarium species associated with fruit rot of banana (Musa spp.), papaya (Carica papaya) and guava (Psidium guajava). Malaysian Journal of Microbiology 8(2): 127-130. 
Zulhaimi, H.I., Rosli, I.R., Kasim, K.F., Akmal, H.M., Nuradibah, M.A. \& Sam, S.T. 2017. A comparative study of Averrhoa bilimbi extraction method. In AIP Conference Proceedings. AIP Publishing LLC. 1885(1): 020178.

Nur Baiti Abd Murad, Muskhazli Mustafa \& Nur Ain Izzati Mohd Zainudin*

Department of Biology, Faculty of Science

Universiti Putra Malaysia

43400 UPM Serdang, Selangor Darul Ehsan

Malaysia
Khozirah Shaari

Department of Chemistry, Faculty of Science

Universiti Putra Malaysia

43400 UPM Serdang, Selangor Darul Ehsan

Malaysia

*Corresponding author; email: ainizzati@upm.edu.my

Received: 22 June 2020

Accepted: 31 October 2020 